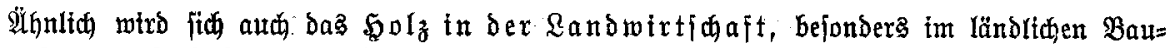

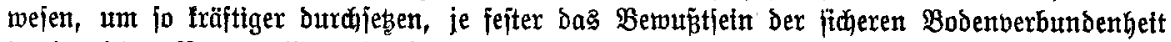

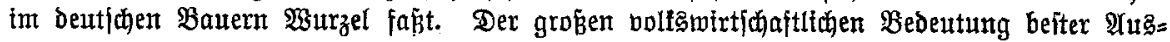
nubutung ber geringen $\mathfrak{5}$ olz

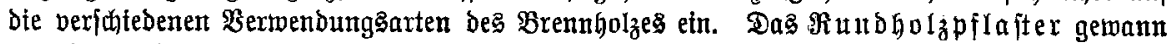

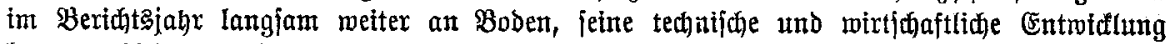

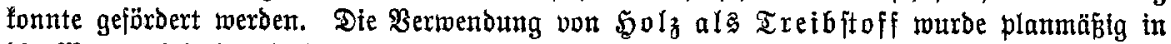

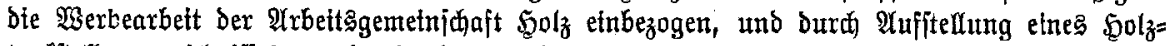

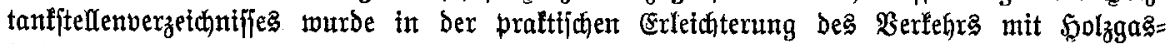
fraftfahr

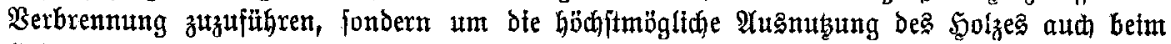

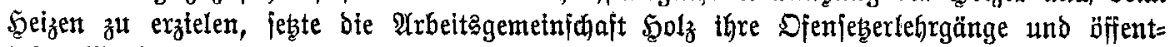

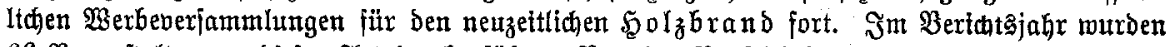

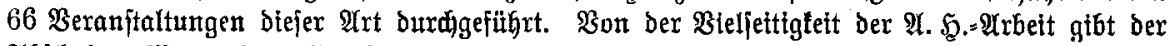

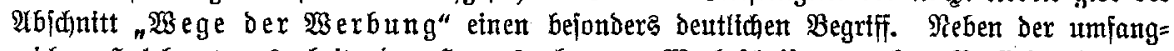

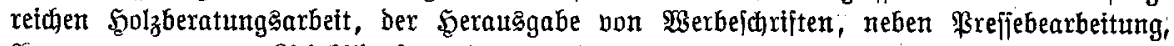

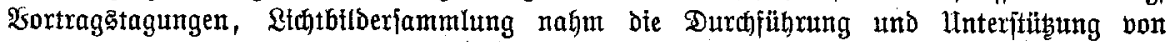

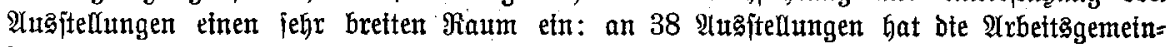

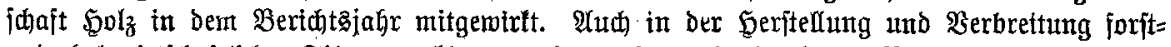

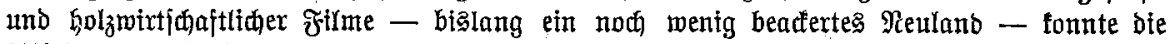

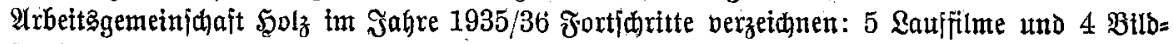

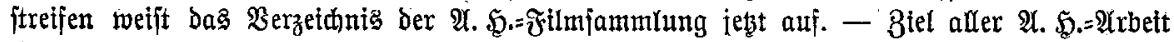

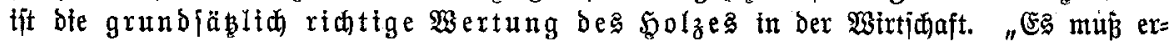

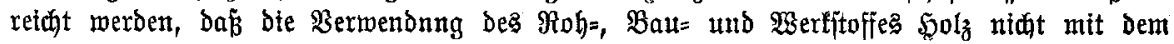

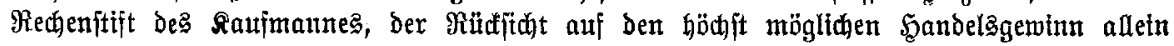

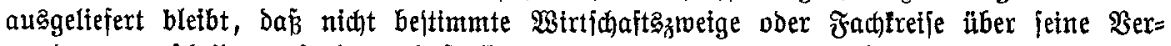

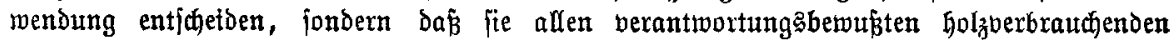

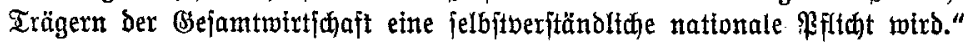

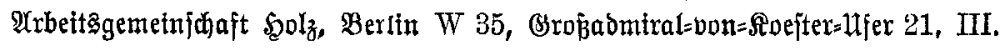

\title{
Dont der $\mathfrak{U}$ niverfität 2rünđh̆en.
}

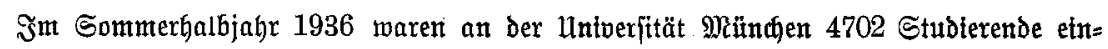

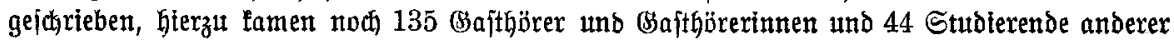

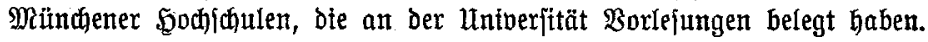

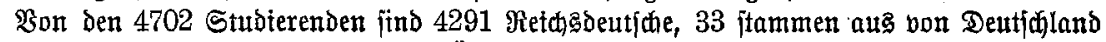
abgetrennten Btebteten, 44 aนs Deutich=: und 145 aủ aup̃ereuropäijđen \&ändern, Dazu fonmen 6 Stantenloje.

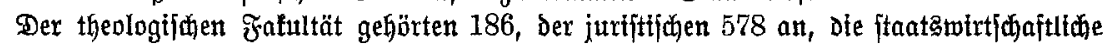

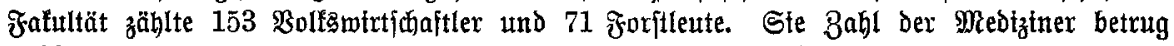
1909, Der 3ahnheilfunde widmeten fid) 264, Der Tterhetlfunde 240, Der \$Garmażie 171. Der phtlofopgtifthen Fafultüt I. Seftton geförten 739, der II. Seftton 391 an.

Itnter Den 4702 Stttoterenden waren 857 Fratten, Darunter 778 Reiddşdeutiche. Der

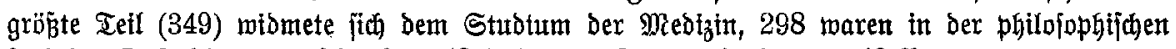

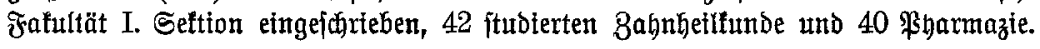

\section{Geheimtrat Ģausrath 70 Jaḩre alt.}

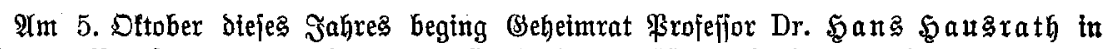

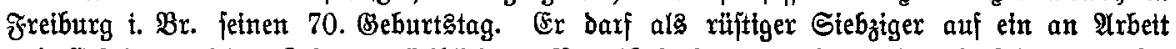

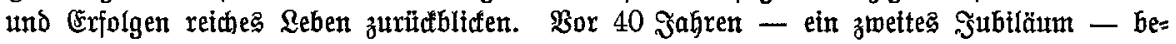

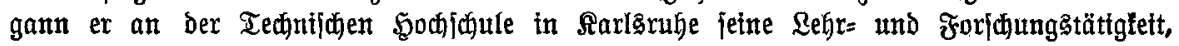

